
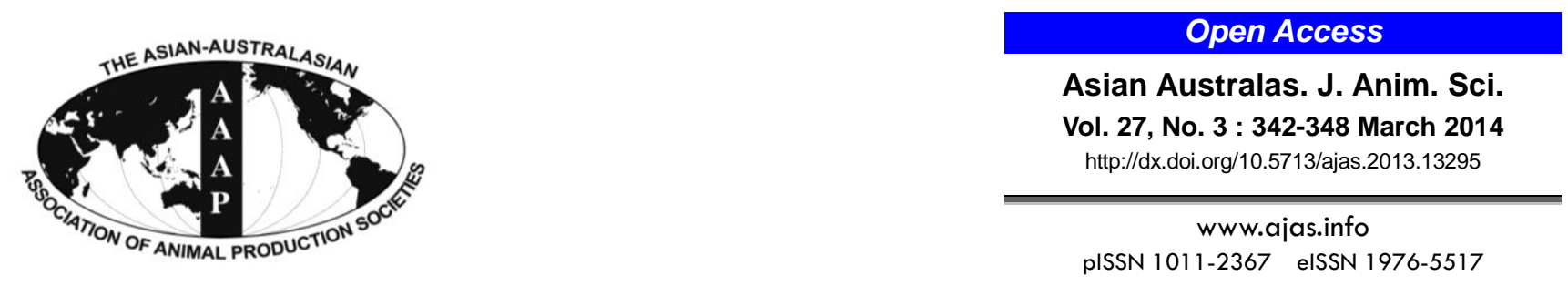

\title{
Influence of Condensed Tannins from Ficus bengalensis Leaves on Feed Utilization, Milk Production and Antioxidant Status of Crossbred Cows
}

\author{
Avijit Dey* and Partha Sarathi De ${ }^{1}$ \\ Regional Research Sub-Station and Krishi Vigyan Kendra, Uttar Banga Krishi Viswavidyalaya, \\ Ratua, Malda- 732 205, India
}

\begin{abstract}
This study was conducted to examine the effects of condensed tannins (CT) from Ficus bengalensis leaves on the feed utilization, milk production and health status of crossbred cows. Eighteen crossbred dairy cows at their second and mid lactation (avg. BW $351.6 \pm 10.6 \mathrm{~kg}$ ) were randomly divided into two groups of nine each in a completely randomized block design and fed two isonitrogenous supplements formulated to contain $0 \%$ and $1.5 \% \mathrm{CT}$ through dried and ground leaves of Ficus bengalensis. The diets were designated as CON and FBLM, respectively and fed to cows with a basal diet of rice straw to meet requirements for maintenance and milk production. The daily milk yield was significantly $(\mathrm{p}<0.05)$ increased due to supplementation of FBLM diet. The $4 \%$ fat corrected milk yield was also significantly $(\mathrm{p}<0.01)$ higher due to increased $(\mathrm{p}<0.05)$ milk fat in cows under diet FBLM as compared to CON. The inclusion of $\mathrm{CT}$ at $1.5 \%$ in the supplement did not interfere with the feed intake or digestibility of DM, OM, CP, EE, NDF, and ADF by lactating cows. Digestible crude protein (DCP) and total digestible nutrients (TDN) values of the composite diets were comparable between the groups. The blood biochemical parameters remained unaltered except significantly $(p<0.05)$ lowered serum urea concentration in cows fed FBLM diet. There was a significant $(\mathrm{p}<0.05)$ increase intracellular reduced glutathione $(\mathrm{GSH})$, superoxide dismutase (SOD) and catalase (CAT) activity in cows supplemented with condensed tannins. The total thiol group (T-SH) was found to be higher with reduction in lipid peroxidation (LPO) in cows of FBLM group. The cost of feeding per kg milk production was also reduced due to supplementation of Ficus bengalensis leaves. Therefore, a perceptible positive impact was evident on milk production and antioxidant status in crossbred cows during mid-lactation given supplement containing $1.5 \%$ CT through Ficus bengalensis leaves. (Key Words: Condensed Tannins, Ficus bengalensis Leaves, Milk Production, Nutrient Utilization, Antioxidant Enzymes, Cows)
\end{abstract}

\section{INTRODUCTION}

Tannins are heterogeneous group of high molecular weight phenolic compounds with the capacity to form reversible and irreversible complexes with mainly proteins (Mangan, 1988; Schofield et al., 2001). The tannins have traditionally been divided into two groups, the condensed and hydrolysable tannins. Hydrolysable tannins (HT) are

\footnotetext{
* Corresponding Author: Avijit Dey. Buffalo Nutrition Division, Central Institute for Research on Buffaloes, Sirsa Road, Hisar125 001, Haryana, India. Tel: +91-9728-334810, Fax: +91-1662275004, E-mail: avijitcirb@gmail.com

1 Department of Botany, Sonamukhi College, University of Burdwan, Sonamukhi, Bankura- 722 207, West Bengal, India. Submitted May 22, 2013; Accepted Sept. 30, 2013; Revised Nov. 6, 2013
}

made up of a carbohydrate core whose hydroxyl groups are esterified with phenolic acids. The condensed tannins (CT) are non-branched polymers of flavonoids units, usually have a higher molecular weight than the HT (1000-20000 Da compared to 500-3000 Da; Mueller-Harvey, 1999).

The beneficial or detrimental effect of tannins to ruminants is depended upon the amount of consumption, the compound's structure and molecular weight and on the physiology of the consuming species (Hagerman and Butler, 1991). The basic goal of protein nutrition in ruminants is to optimize dietary protein use in order to maximize animal growth and milk production per unit of protein consumed. Extensive degradation of dietary protein not only results in wastage, particularly in productive ruminants such as lactating cows, which have high protein requirements but

Copyright (? 2014 by Asian-Australasian Journal of Animal Sciences This is an open-access article distributed under the terms of the Creative Commons Attribution Non-Commercial License (http://creativecommons.org/licenses/by-nc/3.0/), which permits unrestricted non-commercial use, distribution, and reproduction in any medium, provided the original work is properly cited. 
also adds to the cost of production and ultimately leads to environmental pollution. Moreover, an increasing number of consumers demanding healthy and natural foods have pushed organic livestock farming that is reputed to be environment friendly, sustains animals in good health, has high welfare standards and prohibits routine use of growth promoters and chemicals to protect proteins from ruminal degradation (NPOP, 2005). CT from tropical tree leaves have the potential to reduce ruminal degradation of nitrogen to the benefit of animals (Dey et al., 2006). Proteins form complexes with $\mathrm{CT}$ that are stable over the $\mathrm{pH}$ range 3.5 to 7.0 , but dissociate in the abomasum and anterior duodenum. This complex protects proteins from microbial hydrolysis and deamination in the rumen and increases the feed proteins available for digestion and absorption post-rumen (Getachew et al., 2000; Min et al., 2003; Dutta et al., 2012). Proanthocyanidins and their reported digestion products also have high antioxidant activity (Bors and Michel, 2002; Dai and Mumper, 2010) that reduces the risk of several diseases. However the effects of CT in ruminants vary with the type of tannins or plant source (Hagerman et al., 1992; Bhat et al., 2013). Ficus bengalensis also known as Indian Banyan is a large and extensive growing tree of the Indian subcontinent and its leaves are rich source of CT. This study, therefore, aimed to assess the effect of condensed tannins from Ficus bengalensis leaves on feed intake and utilization, lactation performance and antioxidant status of crossbred cows.

\section{MATERIALS AND METHODS}

The experiment was conducted in an organized farm of
Ratua block $\left(25^{\circ} 20^{\prime} \mathrm{N}\right.$ latitude and $87^{\circ} 93^{\prime} \mathrm{E}$ longitude) of Malda district in West Bengal Province of India. The area is situated in an old alluvial zone of river Ganga, having an average annual rain fall of $1,450 \mathrm{~mm}$. Mixed farming involving crops and livestock integration has been a way of life in this region. Despite the importance of livestock, inadequate nutrition is a common problem in small mixed farms and a major factor affecting the development of commercially viable livestock production system.

\section{Animals and diets}

Eighteen lactating crossbred (Bos taurus $\times$ Bos indicus) cows $(345.65 \pm 9.32 \mathrm{~kg})$ at their second and mid lactation (milk yield $7.24 \pm 0.45 \mathrm{~kg} / \mathrm{d}$ ) were randomly allocated into two dietary treatments in a completely randomized block design. Prior to start of the experiment the cows were treated with broad-spectrum anthelmintic (Albendazole suspension [Smith Kline Pharmaceuticals Limited, India] at $2 \mathrm{~mL} / 10 \mathrm{~kg} \mathrm{BW})$. The animals were housed in cementfloored well ventilated sheds with individual feeding provision and free access of fresh water. Two isonitrogenous supplements were formulated containing $0 \%$ and $1.5 \%$ CT supplied from dried and ground leaves of $F$. bengalensis. The diets, designated as control $(\mathrm{CON})$ and Ficus bengalensis leaf meal (FBLM), consisted of rice straw (ad libitum), maize green $(5 \mathrm{~kg})$ and the respective supplements (Table 1), and fed so as to meet the requirements (Kearl, 1982) for maintenance and milk production.

Ficus bengalensis leaves were harvested in one lot in the month of August from the institute campus. The leaves

Table 1. Ingredients and chemical composition of supplements, Ficus bengalensis leaves and green maize

\begin{tabular}{|c|c|c|c|c|c|}
\hline \multirow{2}{*}{ Constituents } & \multicolumn{2}{|c|}{ Supplements $^{1}$} & \multirow{2}{*}{$\begin{array}{c}\text { Ficus } \\
\text { bengalensis }\end{array}$} & \multirow{2}{*}{ Maize green } & \multirow{2}{*}{ Rice straw } \\
\hline & $\mathrm{CON}$ & FBLM & & & \\
\hline \multicolumn{6}{|l|}{ Ingredients $(\mathrm{kg})$} \\
\hline Maize grain & 30.0 & 30.0 & - & - & - \\
\hline Mustard cake & 30.0 & 30.0 & - & - & - \\
\hline Rice bran & 37.0 & 25.1 & - & - & - \\
\hline F. bengalensis leaves & - & 11.9 & - & - & - \\
\hline Mineral mixture $^{2}$ & 2.0 & 2.0 & - & - & - \\
\hline Common salt & 1.0 & 1.0 & - & - & - \\
\hline \multicolumn{6}{|c|}{ Chemical composition (\% DM) } \\
\hline $\mathrm{OM}$ & 91.9 & 91.2 & 85.2 & 89.7 & 88.7 \\
\hline $\mathrm{CP}$ & 18.3 & 18.0 & 10.9 & 6.8 & 3.9 \\
\hline $\mathrm{EE}$ & 2.3 & 2.2 & 3.9 & 1.7 & 1.3 \\
\hline Total ash & 8.1 & 8.8 & 14.8 & 10.3 & 11.3 \\
\hline $\mathrm{NDF}$ & 35.4 & 38.3 & 42.5 & 67.3 & 78.6 \\
\hline $\mathrm{ADF}$ & 17.2 & 23.8 & 36.9 & 42.8 & 51.3 \\
\hline Condensed tannins ${ }^{3}$ & - & 1.5 & 12.6 & - & - \\
\hline
\end{tabular}

${ }^{1} \mathrm{CON}=$ Control supplement; FBLM $=1.5 \%$ CT containing supplement.

${ }^{2}$ Mineral mixture contained $(\mathrm{g} / \mathrm{kg}$ ): Calcium 215, phosphorus 95, sodium chloride 285, potassium iodide 2.5, iron 5.0, copper 0.8, cobalt 1.0, manganese 1.0 and sulphur 1.0 .

${ }^{3}$ It was assumed that only F. bengalensis contains CT, and CT content of the supplement FBLM was calculated accordingly. 
were dried and ground in an electric grinder before mixing in the supplement. Dried and ground leaves of $F$. bengalensis were incorporated in the supplement of FBLM diet to replace rice bran with $\mathrm{CT}$ content at $1.5 \%$ of supplement on dry matter basis. The ingredients and chemical composition of the supplements, F. bengalensis leaves and maize green are given in Table 1. The amount of supplements offered to individual cows was adjusted weekly as per the milk yield of each animal to meet the requirement.

\section{Experimental procedures}

The daily allowance of the supplements was offered in two equal meals in the morning $(07: 00 \mathrm{~h})$ and in the afternoon (16:00 h) during the time of milking. Green maize $(5 \mathrm{~kg})$ and rice straw (ad libitum) were offered at 10:00 h, when all the cows had consumed the concentrates. Straw residues remaining were weighed $24 \mathrm{~h}$ post-feeding to ascertained daily feed consumption. The feeding trial was carried out for 75 days duration including the first 15 days for adaptation and subsequent 60 days for measurement. Milking was done twice daily (7:00 $\mathrm{h}$ and 16:00 h) and daily milk yield of individual cows were recorded throughout the experiment. Milk samples (50 mL each) from each cow were drawn once a week for analysis of milk composition and stored at $4^{\circ} \mathrm{C}$ after adding 2 to 3 drops of potassium dichromate as a preservative, until further analysis.

A digestion trial of 6 days duration was conducted towards the end of experimental feeding. Samples of feed offered and refused were collected daily. The daily feed intake and faecal output from individual cows were recorded. A sub-sample of faeces (1/200th of daily voids) collected and dried at $80 \pm 2^{\circ} \mathrm{C}$ for $24 \mathrm{~h}$ in a forced-draft oven for dry matter estimation. Pooled samples (6 days for each animal) were ground and stored for chemical analysis.

\section{Collection and processing of blood samples}

The blood samples were collected via jugular vein puncture in the morning before feeding and watering of each animal at 0,30 , and 60 days of post feeding. Serum was separated and preserved at $-20^{\circ} \mathrm{C}$ for analyses of glucose, urea, serum proteins and enzymes. Another $2 \mathrm{~mL}$ blood sample was collected in vials containing ethylene diamine tetra-acetate at $1 \mathrm{mg} / \mathrm{mL}$ blood, for haemoglobin and packed cell volume (PCV). For the measurement of antioxidant profile, blood samples were collected aseptically from jugular vein of cows in $15 \mathrm{~mL}$ calibrated tube with acid citrate dextrose $(1.5 \mathrm{~mL} / 10 \mathrm{~mL}$ blood $)$ as anticoagulant and centrifuged at 2,000 rpm for $15 \mathrm{~min}$ at $4^{\circ} \mathrm{C}$, followed by separation of plasma and buffy coat. The resulting erythrocyte pellet was washed thrice with 250 $\mathrm{mOsm} / \mathrm{L}(\mathrm{pH}-7.4)$ phosphate buffered saline (PBS) as per
Yagi et al. (1989). The erythrocyte pellet (packed RBC) thus obtained was mixed with an equal volume of PBS to form RBC suspension. A haemolysate of 1:20 dilution was prepared by mixing $0.5 \mathrm{ml}$ RBC suspension with $4.5 \mathrm{~mL}$ stabilizing solution (EDTA, $2.7 \mathrm{mM}$ and $0.7 \mathrm{mM}$, mercaptoethanol).

\section{Chemical and statistical analyses}

Samples of feeds, residues and faeces were milled to pass through a $1 \mathrm{~mm}$ sieve and analyzed following the methods of the Association of Official Analytical Chemists (1995) to determine DM by oven drying method (934.01), organic matter by muffle furnace incineration (967.05), crude protein by kjeldahl method (984.13), ether extract (920.39), ash (942.05). Neutral detergent fibre (NDF) and acid detergent fibre (ADF) were estimated by the methods of Van Soest et al. (1991). The total phenolics and tannin fractions of $F$. bengalensis leaves were estimated by Butanol-HCl method (Makkar, 2000). Milk samples were warmed in water bath at $38^{\circ} \mathrm{C}$ and mixed for homogenous solution and analyzed for total solids, total ash, total protein and fat content (ISI, 1961).

Haemoglobin and packed cell volume (PCV) were estimated in whole blood immediately after collection by acid haematin method (Benjamin, 1985) and Wintrobe's tube (Hawk, 1965), respectively. Serum glucose concentration was determined colorimetrically (Hultmann, 1989). The serum total protein and albumin content were measured as per Wotton (1964) and Doumas et al. (1971), respectively. Serum urea was estimated by improved diacetyl monoxime method (Rahmatulla and Boyde, 1980). Activity of serum enzymes, aspartate aminotransferase (AST) and alanine aminotransferase (ALT) were estimated as per standard methods described Reitman and Frankel (1957).

The antioxidant status of the animals as influenced by dietary supplementation of condensed tannins was assessed through estimation of antioxidant enzymes viz. catalase (CAT), superoxide dismutase (SOD) and lipid peroxidation (LPO), reduced glutathione (GSH) and total thiol (T-SH) groups in the erythrocytes. The GSH and CAT were estimated by Dithio-bis-2 nitro benzoic acid (DTNB) method of Prins and Loos (1969) and Bergmeyer (1983), respectively. The SOD activity was expressed as $\mathrm{mM}$ of MTT (3-[4-5 dimethyl thiazol 2-xl] 2, 5 diphenyl tetrazolium bromide) formazon formed per $g$ of haemoglobin as per the method described by Madesh and Balasubramanian (1998). The lipid peroxides level was determined by estimating the concentration of malonaldialdehyde (MDA) in $\mathrm{nmol} / \mathrm{g}$ of haemoglobin (Placer et al., 1966). T-SH groups were determined following the method of Sedlak and Lindsay (1968).

The results obtained were subjected to analysis of 
variance in a completely randomized design and the significance of differences between the treatment means was determined using the student t-test by SPSS 11.0 software according to Snedecor and Cochran (1994).

\section{RESULTS AND DISCUSSION}

The chemical composition (\% DM) of $F$. bengalensis leaves, green maize (Zea mays) fodder and concentrate supplements offered to lactating crossbred cows (Table 1) was within the normal range for Indian feeds and fodder (Ranjhan, 2004). The leaves of $F$. bengalensis were found to be a rich source of CT (12.6\%). The total phenolic (19.6\%), total tannin phenolics $(16.1 \%)$ and non-tannin phenolics $(3.5 \%)$ were also recorded as high in the leaves. The composition of supplement with leaves of $F$. bengalensis (FBLM) and without leaves (CON) was comparable, except higher fibre fractions in FBLM as compared to CON. Higher concentration of NDF and ADF in FBLM could be attributed to increased proportion of cell-wall constituents usually present in leaf meal (Anbarasu et al., 2004; Dey et al., 2008).

Total DM intake $\left(\mathrm{g} / \mathrm{kg} \mathrm{W}^{0.75}\right)$ and the digestibility coefficient $(\%)$ of various nutrients were comparable ( $>0.05)$ between both the groups of lactating cows. The nutrient density (\%) of composite diets in terms of DCP and TDN was similar (Table 2). Intake of DOM, DCP, and TDN $\left(\mathrm{g} / \mathrm{kg} \mathrm{W}^{0.75}\right)$ did not vary significantly $(\mathrm{p}>0.05)$ between treatment groups. The comparable $(p>0.05)$ intake by

Table 2. Feed Intake, nutrient digestibility and plane of nutrition of crossbred cows without or with CT supplementation

\begin{tabular}{|c|c|c|c|}
\hline \multirow{2}{*}{ Attributes } & \multicolumn{2}{|c|}{ Treatments } & \multirow{2}{*}{ SEM } \\
\hline & $\mathrm{CON}$ & FBLM & \\
\hline \multicolumn{4}{|l|}{ Body weight } \\
\hline $\mathrm{kg}$ & 345.5 & 357.8 & 10.6 \\
\hline Metabolic $\left(\mathrm{W}^{0.75}\right)$ & 80.1 & 82.3 & 1.82 \\
\hline \multicolumn{4}{|l|}{ Intake $\left(\mathrm{g} / \mathrm{kg} \mathrm{W}^{0.75}\right)$} \\
\hline $\mathrm{DM}$ & 113.2 & 122.1 & 5.34 \\
\hline \multicolumn{4}{|c|}{ Nutrient digestibility (\%) } \\
\hline $\mathrm{DM}$ & 57.6 & 56.9 & 1.70 \\
\hline $\mathrm{OM}$ & 61.5 & 60.7 & 1.56 \\
\hline $\mathrm{CP}$ & 60.4 & 59.1 & 1.38 \\
\hline $\mathrm{EE}$ & 67.4 & 66.3 & 1.43 \\
\hline NDF & 51.3 & 50.6 & 1.84 \\
\hline $\mathrm{ADF}$ & 39.6 & 39.1 & 1.93 \\
\hline \multicolumn{4}{|l|}{ Nutrient density (\%) } \\
\hline DCP & 7.5 & 7.0 & 0.13 \\
\hline TDN & 58.3 & 57.8 & 1.26 \\
\hline \multicolumn{4}{|c|}{ Nutrient intake $\left(\mathrm{g} / \mathrm{kg} \mathrm{W}^{0.75}\right)$} \\
\hline DOM & 60.3 & 67.4 & 2.86 \\
\hline DCP & 8.2 & 8.1 & 0.30 \\
\hline $\mathrm{TDN}^{1}$ & 63.8 & 71.1 & 3.11 \\
\hline
\end{tabular}

${ }^{1}$ TDN calculated from DOM (1 kg DOM $=1.05 \mathrm{~kg}$ TDN; NRC, 2001). crossbred cows irrespective of dietary treatments are in agreement with the earlier observations (Wang et al., 1996a,b; Bwire et al., 2004) that moderate levels (1\% to $4 \%$ ) of CT in the diet from various plant sources exerted no significant effect on feed intake. In the present study, the inclusion of CT at $1.5 \%$ of supplement did not seem to interfere with rumen microbial fermentation or post rumen digestion, therefore, there were similar $(p>0.05)$ digestibility values for various nutrients. All the experimental animals had enough nutrients (DCP and TDN) irrespective of dietary treatments to meet the requirements for maintenance and milk production (Kearl, 1982). The absence of any detectable adverse effect on the health of experimental animals suggests that cows were on balanced diets with no apparent deleterious consequences. The findings suggest that plane of nutrition was not affected adversely with CT supplementation constant with earlier reports (Bhatta et al., 2000; Dey et al., 2008) indicating no adverse effect of dietary inclusion of moderate level (approximately below 5\%) of CT on nutrient intake and utilization.

Supplementation of CT significantly $(\mathrm{p}<0.05)$ increased the daily milk yield of crossbred cows. Interestingly, there was significant $(p<0.05)$ improvement in milk fat content of CT supplemented animals. The increased milk fat and daily milk yield had an additive significant $(\mathrm{p}<0.01)$ positive effect on $4 \%$ fat corrected milk (FCM) yield in crossbred cows given CT supplement (Table 3). The efficiency of milk production ( $\mathrm{kg}$ intake/kg FCM yield) was also

Table 3. Effect of CT supplementation through $F$. bengalensis leaves on milk yield and composition by crossbred cows

\begin{tabular}{|c|c|c|c|}
\hline \multirow{2}{*}{ Attributes } & \multicolumn{2}{|c|}{ Treatments } & \multirow{2}{*}{ SEM } \\
\hline & $\mathrm{CON}$ & FBLM & \\
\hline \multicolumn{4}{|l|}{ Milk yield } \\
\hline $\mathrm{kg} / \mathrm{d}$ & $7.56^{\mathrm{a}}$ & $9.43^{\mathrm{b}}$ & 0.82 \\
\hline $4 \%$ FCM $(\mathrm{kg} / \mathrm{d})$ & $7.41^{\mathrm{a}}$ & $9.78^{\mathrm{b}}$ & 0.51 \\
\hline \multicolumn{4}{|l|}{ Economics of feeding } \\
\hline Cost of supplement (Rs./d) & 62.16 & 68.26 & - \\
\hline Cost of green maize(Rs./d) & 7.50 & 7.50 & - \\
\hline Cost of rice straw (Rs./d) & 15.32 & 15.75 & - \\
\hline Total feed cost (Rs./d) & 84.98 & 91.51 & - \\
\hline $\begin{array}{l}\text { Feeding cost } \\
\text { (Rs./kg milk production) }\end{array}$ & 11.24 & 9.70 & - \\
\hline \multicolumn{4}{|l|}{ Milk composition (\%) } \\
\hline Fat & $3.87^{\mathrm{a}}$ & $4.26^{\mathrm{b}}$ & 0.11 \\
\hline Protein & 3.76 & 3.80 & 0.12 \\
\hline Total ash & 0.78 & 0.80 & 0.01 \\
\hline Total solids & $13.2^{\mathrm{a}}$ & $13.9^{\mathrm{b}}$ & 0.09 \\
\hline EMP & $1.22^{\mathrm{b}}$ & $1.03^{\mathrm{a}}$ & 0.02 \\
\hline
\end{tabular}

Fat corrected milk. 
improved $(p<0.05)$ in CT supplemented cows. The improvement in milk production performance by the action of CT could be due to the increased supply of amino acids at the tissue levels due to protection of dietary proteins (Garg et al., 2005; Dey et al., 2008). Methionine and lysine are the two most important limiting amino acids for the productive performance of animals. Chalupa and sniffen (1996) also reported that increased supply of essential amino acids in protected protein causes an increase in milk production. Methionine in particular, plays a significant role as a methyl donor during milk fat synthesis, and is also the precursor for phospholipids components i.e. choline synthesis (Sharma et al., 1988). Supplementation of $F$. bengalensis leaves could have provided additional volatile fatty acids essential for milk fat synthesis as reported by Wanapat et al. (2000) in lactating dairy cows fed CT rich cassava hay. The increase in milk fat of CT supplemented cows is also supported by the observations of local farmers that dairy cows fed tanniferous leaves produce more butter.

The haemoglobin $(\mathrm{Hb})$, packed cell volume (PCV) and serum glucose level of all the experimental cows (Table 4) were within normal range and showed no significant ( $>0.05$ ) variation due to dietary modification (Kaneko, 1997; Patra et al., 2003). An increased or decreased level of serum glucose level is an indicator of stress to the animals. However, in the present study, similar glucose levels indicated normal physiological condition of all the experimental animals. By contrast, Wang et al. (1996a) reported lower plasma glucose levels in lactating ewes grazed on tanniferous Lotus corniculatus pasture. Total serum protein, albumin, globulin and A:G ratio remained similar for all the animals, which clearly indicates that low levels of CT did not have any adverse effect on all the three parameters. The comparable AST and ALT levels observed in this study reflect no adverse effect of CT supplement $(1.5 \%)$ on liver and muscles. However, significantly

Table 4. Effect of dietary inclusion of condensed tannins through Ficus bengalensis leaves on hemato-biochemical parameters of crossbred cows

\begin{tabular}{lccc}
\hline \multirow{2}{*}{ Attributes } & \multicolumn{2}{c}{ Treatments } & \multirow{2}{*}{ SEM } \\
\cline { 2 - 3 } & CON & FBLM & \\
\hline Haemoglobin (g/dL) & 10.4 & 10.2 & 0.21 \\
PCV (\%) & 32.4 & 31.8 & 0.30 \\
Glucose (mg/dL) & 59.8 & 60.6 & 0.83 \\
Total protein (g/dL) & 5.9 & 5.8 & 0.11 \\
Albumin (g/dL) & 3.2 & 3.3 & 0.16 \\
Globulin (g/dL) & 2.7 & 2.5 & 0.07 \\
A:G ratio & 1.2 & 1.3 & 0.06 \\
Serum urea (mg/dL) & $32.4^{\mathrm{b}}$ & $25.6^{\mathrm{a}}$ & 0.62 \\
ALT (units/mL) & 12.5 & 13.3 & 0.74 \\
AST (units/mL) & 22.8 & 23.7 & 0.86 \\
\hline
\end{tabular}

$\overline{\mathrm{a}, \mathrm{b}}$ Mean values with different superscripts within a row differ significantly $(\mathrm{p}<0.05)$. $(p<0.05)$ lower concentrations of serum urea observed in cows of the FBLM group may be attributed to the reduced rumen protein breakdown and increased EAA absorption. Similarly, lower plasma/serum urea concentration was reported in sheep grazed either on Lotus pasture (Min et al., 2001) or CT supplementation from Ficus infectoria leaves (Dey et al., 2008) and in kids fed leaves of Prosopis cineraria (Bhatta et al., 2002).

It is well known that antioxidant enzymes play a significant role in the body's defense mechanism by scavenging reactive oxygen species (ROS). Higher intra cellular values of GSH, SOD and CAT in CT supplemented cows (Table 5) are suggestive of higher endogenous antioxidant status (Bisla et al., 2002; Han et al., 2004). GSH, present in high concentration in mammalian cells is important in protecting erythrocytes from damage. The present study showed a significant $(\mathrm{p}<0.05)$ increase GSH level in cows of FBLM group, indicating higher antioxidant status than CON group animals. The significantly higher intra-cellular SOD and CAT activity of CT supplemented cows indicates that moderate levels $(1.5 \%)$ of $\mathrm{CT}$ supplementation from $F$. bengalensis leaves had stimulatory effect upon these enzymes. The findings are in agreement with Ho et al. (1999), who reported that proanthocyanidin A-1 component of tannins from Vaccinium vitis-idaea $\mathrm{L}$ had strong SOD activity. In cellular level, SOD controls the potentially toxic superoxide radical $\left(\mathrm{O}^{2-}\right)$ and dismutate it into $\mathrm{H}_{2} \mathrm{O}_{2}$ and catalase enzymolyzes it into $\mathrm{H}_{2} \mathrm{O}$. The significant effect of CT from $F$. bengalensis on SOD and CAT activity may be related to chemical nature and type of CT present in the leaves, which affect the activity. Thiol groups act as intracellular antioxidants by scavenging free radicals and through enzymatic reactions. The water soluble thiol group protects biological membrane (Moscio et al., 1994). The increased T-SH in CT supplemented animals compared with the control indicates better antioxidant status. Lipid peroxidation is used as an indicator of oxidative stress in cells and tissues. Since, polyunsaturated fatty acids generate malondialdehyde and 4- hydroxyalkenals, the measurement of these compounds could be used as

Table 5. Effect of condensed tannins supplementation on erythrocytic antioxidant indices

\begin{tabular}{lrrr}
\hline \multirow{2}{*}{ Attributes } & \multicolumn{2}{c}{ Treatments } & \multirow{2}{*}{ SEM } \\
\cline { 2 - 3 } & CON & FBLM & \\
\hline Catalase $(\mathrm{mK} / \mathrm{g} \mathrm{Hb})$ & $9.8^{\mathrm{a}}$ & $10.9^{\mathrm{b}}$ & 0.16 \\
SOD & $1.7^{\mathrm{a}}$ & $2.3^{\mathrm{b}}$ & 0.21 \\
$\quad$ (mmol MTT formazon formed & & & \\
$\quad$ /g Hb) & & & \\
LPO (nmol MDA/g Hb) & $74.6^{\mathrm{b}}$ & $64.6^{\mathrm{a}}$ & 1.32 \\
GSH $(\mu \mathrm{mol} / \mathrm{g} \mathrm{Hb})$ & $9.9^{\mathrm{a}}$ & $11.8^{\mathrm{b}}$ & 0.31 \\
T-SH $(\mu \mathrm{mol} / \mathrm{mL} \mathrm{PRBC})$ & $39.4^{\mathrm{a}}$ & $45.7^{\mathrm{b}}$ & 0.86 \\
\hline
\end{tabular}

$\overline{\mathrm{a}, \mathrm{b}}$ Mean bearing different superscript within a row differ significantly $(\mathrm{p}<0.05)$. 
indicators of lipid peroxidation. The lipid peroxidation (LPO) was significantly $(\mathrm{p}<0.05)$ decreased (Table 5) in cows fed diet FBLM. Similar to the present findings, Lin et al. (2001) observed that tannin extract of Terminalia catappa had ability to prevent lipid peroxidation and modification of mitomycin C- induced clasto-genicity. Moreover, the increased concentration of thiol groups could explain the reduced lipid peroxidation, as these are known to play greater protective roles in preventing lipid peroxidation of membranes.

The economics of feeding depends on feed intake, cost of feed as well as efficiency of utilization. The cost of FBLM supplement was determined excluding the cost of leaves, as the farmers usually collect them free of cost deploying family labour. However, this is a labour intensive process which involves collection, drying and grinding which may cost around Rs. $1 / \mathrm{kg}$ DM. Based on current market rate of ingredients, per $\mathrm{kg}$ cost of formulated supplements, CON and FBLM worked out to be Rs. 15.5 and 14.2 (US\$ 1 = Rs. 55.0), respectively. The feeding cost per $\mathrm{kg}$ milk production was reduced (Rs. 11.24 vs 9.7) in cows fed FBLM diet as compared to control.

The present study reveals that Ficus bengalensis leaves could be a potential source of CT. A noticeable positive impact was evident on milk production and antioxidant status in crossbred cows during mid-lactation given supplement containing $1.5 \%$ condensed tannins through $F$. bengalensis leaves.

\section{ACKNOWLEDGEMENT}

The authors sincerely acknowledge the financial assistance made by National Agricultural Innovation Project (NAIP) for conducting this study.

\section{REFERENCES}

Anbarasu, C., N. Dutta, K. Sharma, and M. Rawat. 2004. Response of goats to partial replacement of dietary protein by a leaf meal mixture containing Leucaena leucocephala, Morus alba and Tectona grandis. Small Rumin. Res. 51: 47-56.

AOAC. 1995. Official methods of analysis, 16th edn. Association of Official Analytical Chemists, Washington, DC, USA.

Benjamin, M. M. 1985. Outline of veterinary clinical pathology, 3rd edn. Kalyani Publishers, New Delhi, India.

Bergmeyer, H. U. 1983. UV method of catalase assay. Methods of Enzymatic Analysis. Vol. 3, Weinheim, Deerfield Beach, Florida, Bansal.

Bhat, T. K., A. Kannan, B. Singh, and O. P. Sharma. 2013. Value addition of feed and fodder by alleviating the antinutritional effects of tannins. Agric. Res. 2:189-206.

Bhatta, R., U. Krishnamoorthy, and F. Mohammed. 2000. Effect of feeding tamarind (Tamarindus indica) seed husk as a source of tannin on dry matter intake, digestibility of nutrients and production performance of crossbred dairy cows in mid- lactation. Anim. Feed Sci. Technol. 83:67-74.

Bhatta, R., A. K. Shinde, S. Vaithiyanathan, S. K. Sankhyan, and D. L. Verma. 2002. Effect of polyethylene glycol-6000 on nutrient intake, digestion and growth of kids browsing Prosopis cineraria. Anim. Feed Sci. Technol. 101:45-54.

Bisla, R. S., J. Singh, and D. Krishnamurthy. 2002. Assessment of oxidative stress in buffaloes suffering from diaphragmatic hernia. Indian J. Vet. Surg. 23:77-80.

Bwire, J. M. N., H. Wiktersson, and C. M. Shayo. 2004. Effect of level of Acacia torticollis and Faidherbia albida pods supplementation on the milk quality of dual purpose dairy cows fed grass hay based diets. Livest. Prod. Sci. 87:229-236.

Bors, W. and C. Michel. 2002. Chemistry of the antioxidant effect of polyphenols. Ann. NY Acad. Sci. 957:57-69.

Chalupa, W. and C. J. Sniffen. 1996. Protein and aminoacid nutrition in lactating dairy cattle- today and tomorrow. Anim. Feed Sci. Technol. 58:65-75.

Dai, J. and R. J. Mumper. 2010. Plant phenolics: extraction, analysis and their antioxidant and anticancer properties. Molecules 15:7313-7352.

Dey, A., N. Dutta, K. Sharma, and A. K. Pattanaik. 2006. Evaluation of condensed tannins from tropical tree leaves and its impact on in vitro nitrogen degradability of groundnut cake. Anim. Nutr. Feed Technol. 6:215-222.

Dey, A., N. Dutta, K. Sharma, and A. K. Pattanaik. 2008. Effect of dietary inclusion of Ficus infectoria leaves as a protectant of proteins on the performance of lambs. Small Rum. Res. 75: 105-114.

Doumas, V. T., W. A. Watson, and H. G. Biggs. 1971. Albumin standards and the measurement of serum albumen with bromocresol green. Clin. Chem. Acta. 31:87-96.

Dutta, N., M. Dubey, P. S. Banerjee, A. K. Pattanaik, K. Sharma, P. Kumar, and A. Narang. 2012. Effect of supplementing tanniferous tree leaves mixture on immune response and GI nematodes in kids. Livest. Res. Rural Dev. 24, Article \#35. Retrieved October 20, 2013, from http://www.lrrd.org/lrrd24/ 2/dutt24035.htm

Garg, M. R., P. L. Sherasia, B. M. Bhanderi, S. K. Gulati, and T. W. Scot. 2005. Effect of feeding rumen protected protein on milk production in low yielding crossbred cows. Anim. Nutr. Feed Technol. 5:1-18.

Getachew, G., H. P. S. Makkar, and K. Becker. 2000. Tannins in tropical browses: effects on in vitro microbial fermentation and microbial protein synthesis in media containing different amounts of nitrogen. J. Agric. Food Chem. 48:3581-3588.

Hagerman, A. E. and L. G. Butler. 1991. Tannins and lignins. In: Herbivores: their interactions with secondary plant metabolites, Vol I: The chemical participants (Ed. G. A. Rosenthal and M. R. Berenbaum), Academic Press, NY, USA. pp. 355-388.

Hagerman, A. E., C. T. Robbins, Y. Weerasuriya, T. C. Wilson, and C. McArthur. 1992. Tannin chemistry in relation to digestion. J. Range Manag. 45:57-62.

Hawk, P. B. 1965. Hawk's physiological chemistry. 14th edn. McGraw Hill Book Company, London.

Han, B., S. Yoon, J. Su, H. R. Han, M. Wang, W. Qu, and D. Zhong. 2004. Effects of selenium, copper and magnesium on antioxidant enzymes and lipid peroxidation in bovines fluorosis. Asian- Aust. J. Anim. Sci. 17:1695-1699.

Ho, K.Y., J. S. Huang, C. C. Tsai, T. C. Lin, Y. F. Hsu, and C. C. 
Lin. 1999. Antioxidant activity of tannin component from vaccinium vitis-idaea L. J. Pharm. Pharmacol.51:1075-1078.

Hultmann, E. 1959. Rapid specific method for determination aldohexoses (Aldorac chandes) in body fluid. Nature 103:108109.

ISI. 1961. Indian standards methods of test for dairy industry part I. Chemical analysis of milk, part II. Indian Standards Institute, New Delhi, India.

Kaneko, J. J. 1997. Clinical biochemistry of domestic animals. 5th edn. Academic Press, New York, USA.

Kearl, L. C. 1982. Nutrient requirements of ruminants in developing countries. Int. Feed Stuffs Inst., Utah Agric. Exp. Station, Utah State University, Logan, Utah- 84322, USA. pp. 45-81.

Lin, C. C., Y. F. Hsu, and T. C. Lin. 2001. Antioxidant and free radical scavenging effects of the tannins of Terminalia catappa L. Anticancer Res. 21:237-243.

Madesh, M. and K. A. Balasubramanian. 1998. Microtitre plate assay for superoxide dismutase using MTT reduction by superoxide. Indian J. Biochem. Biophy. 35:184-188.

Makkar, H. P. S. 2000. Quantification of tannins in tree foliage. A laboratory manual for the FAO/IAEA co-ordinated research project on "use of nuclear and related techniques to develop simple tannin assays for predicting and improving the safety and efficiency of feeding ruminants on tanniniferous tree foliage". Joint FAO/IAEA working document, IAEA, Viena.

Mangan, J. L. 1988. Nutritional effects of tannins in animal feeds. Nutr. Res. Rev. 1:209-231.

Min, B. R., J. M. Fernandez, T. N. Barry, W. C. McNabb, and P. D. Kemp. 2001. The effect of condensed tannins in Lotus corniculatus upon reproductive efficiency and wool production in ewes during autumn. Anim. Feed Sci. Technol. 92:185-202.

Min, B. R., T. N. Barry, G. T. Attwood, and W. C. McNabb. 2003. The effect of condensed tannins on the nutrition and health of ruminants fed fresh temperate forages: a review. Anim. Feed Sci. Technol. 106:3-19.

Moscio, A., G. Bufano, A. Sevi, A. Manchisi, G. Martemucci, D. Casamassima, A. Djajanegara, and A. Sukmawati. 1994. Effect of slaughtering age and dietary energy level on productive performance of fattening lambs. In: Proceedings of the 7th AAAP Animal Science Congress, Bali, Indonesia. pp. 75-76.

Mueller-Harvey, I. and A. B. McAllan. 1992. Tannins: Their biochemistry and nutritional properties. In: Advances in plant cell biochemistry and biotechnology, Vol. 1 (Ed. I. M. Morrison). JAI Press Ltd., London,UK. pp. 151-217.

NPOP. 2005. National programme on organic production. Ministry of Commerce and Industry, Govt. of India. pp. 42-46.

National Research Council. 2001. Nutrient requirements of dairy cattle. 7 th Revised Ed. National Academy Press, Washington, DC.
Patra, A. K., K. Sharma, N. Dutta, and A. K. Pattanaik. 2003. Response of gravid does to partial replacement of dietary protein by a leaf meal mixture of Leucaena leucocephala, Morus alba and Azadirachta indica. Anim. Feed Sci. Technol. 109:171-182.

Placer, Z. A., L. L. Cushman, and B. Johnson. 1966. Estimation of product of lipid peroxidation (malonaldehyde) in biochemical system. Anal. Biochem. 16:359-364.

Prins, A. and G. Loos. 1969. Biochemical methods in red cell genetics. Academic Press, pp. 127-129.

Rahmatulla, M. and T. R. C. Boyde. 1980. An improvement in determination of urea usng diacetylmonoxime method with and without deproteinization. Clin. Chem. Acta. 107:3.

Ranjhan, S. K. 2004. Animal nutrition and feeding practices. Sixth edn., Vikas Publishing House Pvt. Ltd., New Delhi, India.

Reitman, S. and S. Frankel. 1957. Determination of serum glutamic-pyruvate transaminase by colorimetric methods. Am. J. Clin. Path. 28:57.

Schofield, P., D. M. Mbugua, and A. N. Pell. 2001. Analysis of condensed tannins: a review. Anim. Feed Sci. Technol. 91:2140.

Sedlak, J. and R. Lindsay. 1968. Estimation of total protein bound and non-protein sulphydril groups in tissue with Ellman's reagent. Anal. Biochem. 25:192-205.

Sharma, B. K. and R. A. Erdman. 1988. Abomasal infusion of choline and methionine with or without 2-amino-2-methyl-1propanol for lactating dairy cows. J. Dairy Sci. 71:2406-2411.

Snedecor, G. W. and W. G. Cochran. 1994. Statistical methods. 8th edn. East West Press Pvt. Ltd., New Delhi, India.

Van Soest, P. J., J. B. Robertson, and B. A. Lewis. 1991. Methods for dietary fibre, neutral detergent fibre and non-starch polysaccharides in relation to animal nutrition. J. Dairy Sci. 74:3583-3597.

Wanapat, M., T. Puramongkon, and W. Siphuak. 2000. Feeding of cassava hay for lactating dairy cows. Asian-Aus. J. Anim. Sci. 13:478-482.

Wang, Y., G. B. Douglas, G. C. Waghorn, T. N. Barry, A. G. Foote, and R. W. Purchas. 1996a. Effect of condensed tannins upon the performance on lambs grazing Lotus corniculatus and lucerne (Medicago sativa). J. Agric. Sci. (Camb.) 126:87-98.

Wang, Y., G. B. Douglas, G. C. Waghorn, T. N. Barry, and A. G. Foote. 1996b. Effect of condensed tannins in Lotus corniculatus upon lactation performance in ewes. J. Agric. Sci. (Camb.) 126:353-362.

Wotton, I. D. P. 1964. Microanalysis in medical biochemistry. 4th edn. G \& A Churchill Ltd., London, WI.

Yagi, Y., S. Furunchi, H. Takashi, and H. Koyama. 1989. Abnormality of osmotic fragility and morphological disorder of bovine erythrocytes infected with Theileria sargonti. Japanese J. Vet. Sci. 51:389-395. 